\title{
Independence of Hydrogen Ion Secretion and Transport of Other Electrolytes in Turtle Bladder *
}

\author{
Philip R. Steinmetz, $\ddagger$ Rodney S. Omachi,§ and Howard S. Frazier \| \\ (From the Departments of Medicine, Harvard Medical School and Beth Israel Hospital, \\ Boston, Massachusetts)
}

\begin{abstract}
The relationship between hydrogen ion secretion and the transport of other electrloytes was examined in the isolated urinary bladder of the water turtle. Symmetrical solutions which were free from exogenous carbon dioxide and bicarbonate bathed the two surfaces of the preparation, and the spontaneous electrical potential of the bladder was nullified by a voltage clamp. Active transport of sodium from mucosal to serosal medium was confirmed by simultaneous bidirectional flux measurements and found to be slightly, but not significantly, greater than the short-circuit current. In the absence of sodium in the bathing solutions, the normal potential difference across the bladder reversed and the current required to nullify this reversed potential difference had the same magnitude as the simultaneously measured rate of hydrogen ion secretion. The results indicate that, under these experimental conditions, the bladder transports sodium and hydrogen ion actively, but that chloride movement does not contribute to the short-circuit current.

The rate of secretion of hydrogen ion was not affected by replacement of the sodium in the bathing media by cesium, or by inhibition of sodium transport by dinitrophenol. Acidification continued when chloride in the solutions was replaced by sulfate, or when potassium or calcium was removed from the solution bathing the mucosal surface.

Secretion of hydrogen ion by the turtle bladder is not dependent on the simultaneous transport of other electrolytes across the bladder.
\end{abstract}

\section{Introduction}

In the preceding article, evidence was presented indicating that $\mathrm{H}^{+}$transport in the urinary bladder of the fresh water turtle cannot be accounted for

* Received for publication 8 February 1967 and in revised form 6 June 1967.

Supported by grants from the American Heart Association, the William F. Milton Fund of Harvard University, the John A. Hartford Foundation, and a General Research Support Grant, 5S01 FR 05479-04, from the U. S. Public Health Service.

Presented in part before the annual meeting of the American Society for Clinical Investigation, 1 May 1966, Atlantic City, N. J. (1).

$\ddagger$ Recipient of U. S. Public Health Service Career Development Award 7-K $\mathrm{K}_{3}-\mathrm{HE}-12,113-03$.

$\S$ Student at Harvard Medical School, recipient of summer fellowship 5T5GM 1651-05 from U. S. Public Health Service. by passive driving forces (2). Acidification of the mucosal medium, therefore, must either be linked directly to metabolic energy production or be coupled to the active transport of another ion. Mechanisms for the active transport of $\mathrm{Na}^{+}$and, under some experimental conditions, for $\mathrm{Cl}^{-}$have been demonstrataed in the bladder in vitro (3-5). The purpose of the present study is to investigate the possibility of coupling between the transport of $\mathrm{H}^{+}$ion and that of $\mathrm{Na}^{+}$and $\mathrm{Cl}^{-}$.

The results indicate that the transport of $\mathrm{H}^{+}$in the turtle bladder is not directly coupled to the

\| Recipient of U. S. Public Health Service Career Development Award 1-K3-HE-31,106.

Address requests for reprints to Dr. Philip R. Steinmetz, Beth Israel Hospital, 330 Brookline Avenue, Boston, Mass. 02215. 
transport of $\mathrm{Na}^{+}$. The rate of $\mathrm{H}^{+}$secretion was little affected by the removal of $\mathrm{Na}^{+}$from the bathing solution or by the reduction of $\mathrm{Na}^{+}$transport which followed treatment with dinitrophenol. Removal of $\mathrm{Cl}^{-}$from the bathing solutions was associated with the continuation of both $\mathrm{H}^{+}$and $\mathrm{Na}^{+}$ transport, although the rates were somewhat reduced. In the absence of $\mathrm{Na}^{+}$the mucosal side of the bladder became positive with respect to the serosal side and the current required to nullify this potential difference $(\mathrm{PD})$ had the same magnitude as the rate of $\mathrm{H}^{+}$secretion. This result suggests that $\mathrm{Cl}^{-}$is not actively transported across the bladder under these experimental conditions.

\section{Methods}

Experimental design. Although these studies were concerned primarily with an examination of coupling between $\mathrm{H}^{+}$secretion and transport of $\mathrm{Na}^{+}$or $\mathrm{Cl}^{-}$, it proved useful to identify the ionic flows that contributed to the short-circuit current (SCC). The ions to be considered are the following: (a) $\mathrm{Na}^{+}$, which is transported actively from the mucosal (M) to serosal (S) medium $(3,4),(b) \mathrm{Cl}^{-}$, which is transported actively from $M$ to $S$ under some experimental conditions (5), and $(c) \mathrm{H}^{+}$, which is transported actively into $\mathrm{M}(2)$.

For the purposes of this study, active transport is defined as net movement of an ion across the bladder in the absence of gradients of concentration or electrical potential. All experiments were performed with the bladder in the short-circuited state and, unless specifically noted, with identical solutions bathing both surfaces of the bladder. Active transport of $\mathrm{Na}^{+}$was determined as the difference between the simultaneously measured fluxes of ${ }^{24} \mathrm{Na}$ and ${ }^{22} \mathrm{Na}$. Since two different radioactive isotopes of $\mathrm{Cl}^{-}$were not available, measurement of active $\mathrm{Cl}^{-}$transport by the definitive double-label experiment was not feasible. An indirect method was used instead. Control of electrochemical gradients for $\mathrm{H}^{+}$was obtained by the use of a $\mathrm{pH}$ stat for the solution bathing one surface of the bladder, with frequent changes in the bathing solution of the other. When isotopic flux measurements were made, the mucosal solution was maintained at constant $\mathrm{pH}$ by the $\mathrm{pH}$ stat. The $\mathrm{pH}$ of the serosal solution was monitored with an additional glass electrode and small volumes of $0.01 \mathrm{M} \mathrm{HCl}$ were added as required to maintain constant $\mathrm{pH}$. In the experiments in which sulfate Ringer's solution was used, the $\mathrm{pH}$ of the serosal solution did not deviate by more than $0.2 \mathrm{pH}$ units from the original value, so no acid was added.

In our hands the variation in transport behavior in two portions of the same turtle bladder was comparable to that shown by two bladders from different animals. For this reason, we performed two general types of experiments: one in which a preparation served as its own control, and one which involved a comparison of two sets of preparations from different turtles.
Two additional features of our experiments require comment. The measurement of $\mathrm{Na}^{+}$fluxes by the isotopic method assumes constant specific activity of the labeled $\mathrm{Na}^{+}$in the transport pool of the epithelial cells. Paine and Foulkes (6) have reported that mixing of $\mathrm{Na}^{+}$ in the turtle bladder preparation is slow. At a $\mathrm{Na}^{+}$concentration similar to the one employed in our experiments they observed that after $30 \min 71 \%$ of cellular $\mathrm{Na}^{+}$ had equilibrated with isotopic $\mathrm{Na}^{+}$. This fraction was only slightly increased to $76 \%$ after $120 \mathrm{~min}$. Under our experimental conditions, $30-40 \mathrm{~min}$ of exposure to ${ }^{24} \mathrm{Na}$ were required before the specific activity of the transported $\mathrm{Na}^{+}$reached a constant value. Therefore, the experimental design included a period of $50 \mathrm{~min}$ between the addition of isotopic $\mathrm{Na}^{+}$and the beginning of flux measurements. In all experiments, the bladder was washed three times in the incubation medium over a period of $1 \mathrm{hr}$ before the addition of the isotope, or the measurement of SCC or $\mathrm{H}^{+}$secretion.

Since the turtle bladder has a relatively low DC resistance, appreciable current were required from the automatic voltage clamp in order to nullify the potential between the sensing salt bridges on the two sides of the bladder. Although special efforts were made to position the tips of the sensing bridges close to the surfaces of the bladder, the resistance of the fluid layer in a series of determinations was occasionally as large as $30 \mathrm{ohms}$. As a result, there was a residual potential difference of the usual orientation across the bladder even in the shortcircuited state, the size of which varied with the SCC and the exact position of the sensing bridges, but which usually was considerably below the maximum value of 10 mv. The available information does not permit derivation of a rigorous expression which can be used to correct the two passive and one active flows of $\mathrm{Na}^{+}$for this deviation from the condition of zero electrical driving force. An approximate correction was calculated by making use of Ussing's flux ratio equation (7) and two assumptions : that the maximal gradient against which the $\mathrm{Na}^{+}$pump can operate is $170 \mathrm{mv}(8)$; and that for small electrical gradients, the change in active transport is linearly related to the change in voltage across the bladder. The calculated correction yielded a small increase in net $\mathrm{Na}^{+}$flux and SCC. Since the difference between the two quantities was the figure of interest, and since the corrections did not change this difference significantly, the interpretation of our results was unaffected. As demonstrated in our previous paper, the rate of $\mathrm{H}^{+}$secretion was so little affected by the presence or absence of the spontaneous transbladder potential that no correction of this flux was required in the evaluation of the SCC. In the experiments with $\mathrm{CsCl}$ Ringer's solution, the short-circuiting error was avoided by application, to the input of the voltage clamp, of an offset potential which was approximately equal to the potential drop in the fluid layer between the sensing bridges.

Experimental procedure. The experimental methods have been described in the previous article (2). The same standard $\mathrm{NaCl}$ Ringer's solution was employed. In addition to the standard Ringer's solution, Na-free 
TABLE I

Comparison of simultaneous $\mathrm{Na}^{+}$fluxes, $\mathrm{H}^{+}$secretion, and short-circuit current $(\mathrm{SCC})$ in turtle bladder*

\begin{tabular}{|c|c|c|c|c|c|}
\hline Solution & $\frac{{ }^{2 \mathrm{Na}}}{\mathrm{M} \longrightarrow \mathrm{S}}$ & $\frac{{ }^{22} \mathrm{Na}}{\mathrm{S} \longrightarrow \mathrm{M}}$ & $\frac{\mathrm{Na}}{\mathrm{M} \stackrel{\text { net }}{\longrightarrow} \mathrm{S}}$ & $\begin{array}{c}\mathrm{H}^{+} \\
\longrightarrow \mathrm{M}\end{array}$ & $\mathrm{SCC}$ \\
\hline $\begin{array}{l}\mathrm{NaCl} \text { Ringer's, } 30 \text { periods, } 9 \text { turtles } \\
\mathrm{Na}_{2} \mathrm{SO}_{4} \text { Ringer's, } 27 \text { periods, } 11 \text { turtles }\end{array}$ & $\begin{array}{l}349 \pm 26 \\
253 \pm 20\end{array}$ & $\begin{array}{l}53 \pm 11 \\
78 \pm 13\end{array}$ & $\begin{array}{c}\mu a \\
296 \pm 25 \\
175 \pm 20\end{array}$ & $\begin{array}{l}26 \pm 2 \\
13 \pm 1\end{array}$ & $\begin{array}{l}280 \pm 24 \\
168 \pm 20\end{array}$ \\
\hline
\end{tabular}

M, mucosa; S, serosa.

* All experimental periods were $30 \mathrm{~min}$.

$\ddagger$ Statistical variation is expressed as \pm 1 SEM.

and Cl-free solutions of the following composition were prepared : $\mathrm{CsCl}$ Ringer's (mmoles/liter) : $\mathrm{Cs}^{+}, 114.4 ; \mathrm{K}^{+}$, $4.1 ; \mathrm{Ca}^{++}, 0.9 ; \mathrm{Cl}^{-}, 119.8 ; \mathrm{HPO}_{4}=0.3$; and glucose 2.0 ; osmolality, $227 \mathrm{mOsm} / \mathrm{kg} \mathrm{H}_{2} \mathrm{O}$. $\mathrm{Na}_{2} \mathrm{SO}_{4}$ Ringer's (mmoles/liter) : $\mathrm{Na}^{+}, 116.6 ; \mathrm{K}^{+}, 3.6 ; \mathrm{SO}_{4}=59.8 ; \mathrm{HPO}_{4}=$ 0.3 ; $\mathrm{CaSO}_{4}$, saturated solution; glucose, 2.0 ; sucrose to bring osmolality to $227 \mathrm{mOsm} / \mathrm{kg} \mathrm{H}_{2} \mathrm{O}$. To change the bathing solutions, we drained both half chambers and filled them with fresh Ringer's solution four times over a 50 min period to remove either $\mathrm{Na}^{+}$or $\mathrm{Cl}^{-}$from the bathing media and to reduce the tissue concentration of these ions. In the $\mathrm{pH}$ stat experiments the $\mathrm{Na}^{+}$concentration in the bathing solution was determined by flame photometry and the $\mathrm{Cl}^{-}$concentration by electrometric titration. At the beginning of the $\mathrm{pH}$ stat period in the $\mathrm{Na}$-free and $\mathrm{Cl}$-free Ringer's solution the concentrations in the bathing media of these excluded ions were below detection limits of $0.1 \mathrm{mmole} / \mathrm{liter}$; at the end of the $\mathrm{pH}$ stat period the concentrations were less than $1 \mathrm{mmole} /$ liter. In the experiments in which the effect of inhibition of $\mathrm{Na}^{+}$transport on $\mathrm{H}^{+}$secretion was examined, both bathing solutions were exchanged for new Ringer's solution containing $1 \times 10^{-5} \mathrm{M}$ dinitrophenol. All solutions were gassed with air which had passed through an alkali trap and were brought to a final $\mathrm{pH}$ of $7.40 \pm 0.10$. As in the preceding paper, identical solutions and gas phases were employed on both sides of the bladder, all flux periods were of $30 \mathrm{~min}$ duration unless otherwise noted, and fluxes were calculated as $\mu$ moles/hour or amperes. As titrant for the $\mathrm{pH}$ stat assembly either $0.01 \mathrm{~N} \mathrm{NaOH}$ or $0.01 \mathrm{~N} \mathrm{KOH}$ was employed. The volume of titrant added in a given flux period was less than $1.4 \%$ of the volume of incubation medium. ${ }^{24} \mathrm{Na}$ and ${ }^{22} \mathrm{Na}$ were obtained as the $\mathrm{Cl}$ salt from Cambridge Nuclear Corporation (Cambridge, Mass.). Both isotopes were counted in a Nuclear-Chicago model 4218 well counter, ${ }^{24} \mathrm{Na}$ at settings which excluded ${ }^{2} \mathrm{Na}$ activity, and ${ }^{20} \mathrm{Na}$ after a 2 wk delay to permit loss by decay of ${ }^{m} \mathrm{Na}$ activity.

\section{Results}

Short-circuit current in the turtle bladder. The simultaneously determined values of bidirectional $\mathrm{Na}^{+}$fluxes, rate of $\mathrm{H}^{+}$secretion, and $\mathrm{SCC}$, in the presence and absence of $\mathrm{Cl}^{-}$, are shown in Table I. The mean values for net $\mathrm{Na}^{+}$flux from $\mathrm{M}$ to $\mathrm{S}$ were close to the SCC, the former being slightly greater in both series of experiments. If $\mathrm{H}^{+}$secretion into the mucosal fluid involved the transfer of a positive charge, then net $\mathrm{Na}^{+}$transport minus $\mathrm{H}^{+}$transport should account for the SCC in the absence of ambient $\mathrm{Cl}^{-}$. Subtraction of the rate of $\mathrm{H}^{+}$transport from net $\mathrm{Na}^{+}$transport resulted in a value slightly less than the SCC, the SCC value being straddled by the values for net $\mathrm{Na}^{+}$flux alone and net $\mathrm{Na}^{+}$flux minus $\mathrm{H}^{+}$secretion. The algebraic sum of the flux of measured ions differs from the simultaneously measured SCC, but the discrepancies are within the error of the measurement of the net $\mathrm{Na}^{+}$flux. For this reason, the results of these experiments performed in the presence and absence of $\mathrm{Cl}^{-}$do not permit any conclusion regarding the existence of an active transport mechanism for $\mathrm{Cl}^{-}$. In conformity with the findings of others, however, these results indicate that in the absence of passive driving forces net $\mathrm{Na}^{+}$transport is the major constituent of the $\operatorname{SCC}(3,9)$. This fact supports the interpretation that large reductions in the SCC after

TABLE II

Effect of $\mathrm{H}^{+}$secretion of substituting $\mathrm{Cs}^{+}$for $\mathrm{Na}^{+}$in Ringer's solutions bathing turtle bladder

\begin{tabular}{|c|c|c|c|}
\hline \multirow[b]{2}{*}{ Turtle } & \multicolumn{3}{|c|}{$\mathrm{H}^{+}$secretion* } \\
\hline & $\begin{array}{l}\text { Initial } \\
\text { control }\end{array}$ & Cesium & $\underset{\text { control }}{\text { Final }}$ \\
\hline & \multicolumn{3}{|c|}{$\mu$ moles $/ h r$} \\
\hline 1 & 2.66 & 2.16 & 2.42 \\
\hline 2 & 1.00 & 0.71 & 0.40 \\
\hline 3 & 1.30 & 0.69 & 0.46 \\
\hline 4 & 1.67 & 1.30 & 1.80 \\
\hline 5 & 0.69 & 0.77 & 0.71 \\
\hline 6 & 1.20 & 1.10 & 1.20 \\
\hline 7 & 0.84 & 0.80 & 0.65 \\
\hline Mean & 1.33 & 1.08 & 1.09 \\
\hline 土SEM & \pm 0.25 & \pm 0.20 & \pm 0.29 \\
\hline
\end{tabular}

* The experimental periods were of $30-40$ min duration. 
TABLE III

The effects of dinitrophenol (DNP) on acid secretion and short-circuit current $(S C C)$ in the turtle bladder

\begin{tabular}{cccccr}
\hline & \multicolumn{2}{c}{$\mathrm{H}^{+}$secretion } & & \multicolumn{2}{c}{ SCC } \\
\cline { 2 - 3 } \cline { 5 - 6 } Turtle & Control & DNP* & & Control & DNP \\
\hline & \multicolumn{3}{c}{$\mu$ moles $/ h r$} & & \multicolumn{2}{c}{$\mu a$} \\
2 & 1.75 & 1.70 & & 235 & 107 \\
3 & 0.76 & 0.92 & & 173 & 81 \\
4 & 0.83 & 0.89 & & 153 & 100 \\
5 & 0.51 & 0.76 & & 74 & 37 \\
6 & 0.79 & 0.82 & & 131 & 95 \\
Mean & 1.49 & 1.40 & & 210 & 130 \\
ISEM & 1.02 & 1.08 & & 163 & 92 \\
& +0.20 & \pm 0.15 & & \pm 23 & \pm 13
\end{tabular}

* DNP was added to both bathing solutions in a concentration of $1 \times 10^{-5}$ mole/liter. The $\mathrm{H}^{+}$secretion rate represents the mean of a 30 min period, which began $15 \mathrm{~min}$ after addition of DNP. The SCC values were obtained $45 \mathrm{~min}$ after the addition of DNP.

experimental manipulation are the result of similar changes in net $\mathrm{Na}^{+}$flux. It is only in this restricted and qualitative sense that the measurements of SCC in the presence of $\mathrm{Na}^{+}$are to be used in this study.

Effects on $\mathrm{H}^{+}$secretion of altering the rate of $\mathrm{Na}^{+}$transport. The results in Table II show the effects on $\mathrm{H}^{+}$secretion of substituting $\mathrm{Cs}^{+}$for $\mathrm{Na}^{+}$ in the Ringer's solutions of both sides of the epithelium. The concentration of $\mathrm{Na}^{+}$in the medium was $115 \mathrm{mEq} /$ liter during the control period and less than $1 \mathrm{mEq} /$ liter at the end of the period with $\mathrm{CsCl}$ Ringer's solution. $\mathrm{H}^{+}$secretion continued after removal of $\mathrm{Na}^{+}$in all experiments with only slight reductions in the rate of secretion in some. Replacement of $\mathrm{Na}^{+}$failed to cause a consistent increase in secretion rate despite steep increases in $\mathrm{Na}^{+}$transport as judged from the SCC.

If acidification occurs by a process of exchange for $\mathrm{Na}^{+}$, these experimental results require that the mechanism be saturated with respect to $\mathrm{Na}^{+}$when the concentration of the latter is in the micromolar range. This requirement and the experimental results make the existence of such coupling unlikely.

Since dinitrophenol has been shown to cause marked inhibition of $\mathrm{Na}^{+}$transport in the turtle bladder (10), the independence of $\mathrm{H}^{+}$secretion and $\mathrm{Na}^{+}$transport was further tested by exposing the bladder to standard $\mathrm{NaCl}$ Ringer's solutions containing $1 \times 10^{-5} \mathrm{M}$ dinitrophenol. In Table III, $\mathrm{H}^{+}$secretion is shown to be unaffected despite marked decreases in the SCC, and hence the active transport of $\mathrm{Na}^{+}$. The decrease in SCC was that observed at $45 \mathrm{~min}$; at $60 \mathrm{~min}$ the decrease was $65 \%$. The inhibitory effect of dinitrophenol on the SCC was reversed when the bladder was exposed to fresh standard Ringer's solution. The rate of $\mathrm{H}^{+}$secretion remained relatively constant throughout.

Relationship between $\mathrm{H}^{+}$secretion and electrical activity of turtle bladder in Na-free Ringer's solution. Removal of $\mathrm{Na}^{+}$by repeated washes in $\mathrm{CsCl}$ Ringer's solution caused the orientation of the PD across the bladder to reverse, the serosal solution becoming negative with respect to the mucosal solution. The PD in the 2nd and 3rd hr of exposure to $\mathrm{CsCl}$ Ringer's solution ranged from -1 to $-10 \mathrm{mv}$, the mean PD being $-4 \mathrm{mv}$. In most experiments the normal electrical orientation could be restored promptly by replacement of $\mathrm{CsCl}$ with $\mathrm{NaCl}$ Ringer's solution.

In Table IV six experiments are presented in which simultaneous measurements were made of the rate of $\mathrm{H}^{+}$secretion and of the reversed SCC. The rate of $\mathrm{H}^{+}$secretion expressed in $\mu$ amperes closely approximated the reversed SCC. Deoxygenation of the bathing media caused a reduction

TABLE IV

Simultaneous measurement of $\mathrm{H}^{+}$secretion and short-circuit current (SCC) in turtle bladder bathed in sodium-free Ringer's solution

\begin{tabular}{|c|c|c|c|}
\hline Turtle & $\underset{\text { secretion }}{\mathrm{H}^{+}}$ & $\begin{array}{l}\text { Reversed } \\
\text { SCC }\end{array}$ & $\begin{array}{r}\text { Difference, } \\
\mathrm{H}^{+} \text {secre- } \\
\text { tion-SCC }\end{array}$ \\
\hline $1 \underset{\mathrm{N}_{2}}{\mathrm{air}}$ & $\begin{array}{l}20 \\
18\end{array}$ & $\begin{array}{l}25^{\mu a} \\
18\end{array}$ & $\begin{array}{r}-5 \\
0\end{array}$ \\
\hline $2 \underset{\mathrm{N}_{2}}{\mathrm{air}}$ & $\begin{array}{r}14 \\
7\end{array}$ & $\begin{array}{r}10 \\
6\end{array}$ & $\begin{array}{l}4 \\
1\end{array}$ \\
\hline $\begin{array}{c}3 \text { air } \\
\mathrm{N}_{2} \\
\text { air }\end{array}$ & $\begin{array}{r}13 \\
0 \\
20\end{array}$ & $\begin{array}{r}11 \\
7 \\
14\end{array}$ & $\begin{array}{r}2 \\
-7 \\
6\end{array}$ \\
\hline $\begin{array}{l}4 \underset{\text { air }}{\mathrm{N}} \\
\mathrm{N}_{2} \\
\text { air }\end{array}$ & $\begin{array}{l}27 \\
19 \\
39\end{array}$ & $\begin{array}{l}23 \\
17 \\
32\end{array}$ & $\begin{array}{l}4 \\
2 \\
7\end{array}$ \\
\hline $\begin{array}{l}5 \text { air } \\
\mathrm{N}_{2} \\
\text { air }\end{array}$ & $\begin{array}{r}15 \\
0 \\
19\end{array}$ & $\begin{array}{r}20 \\
6 \\
14\end{array}$ & $\begin{array}{l}-5 \\
-6 \\
5\end{array}$ \\
\hline $\begin{array}{c}6 \text { air } \\
\mathrm{N}_{2} \\
\text { air }\end{array}$ & $\begin{array}{r}12 \\
0 \\
20\end{array}$ & $\begin{array}{r}13 \\
5 \\
11\end{array}$ & $\begin{array}{r}-1 \\
-5 \\
9\end{array}$ \\
\hline $\begin{array}{l}\text { Mean } \\
\pm \text { SEM }\end{array}$ & & & $\begin{array}{l}-0.7 \\
\pm 1.2\end{array}$ \\
\hline
\end{tabular}




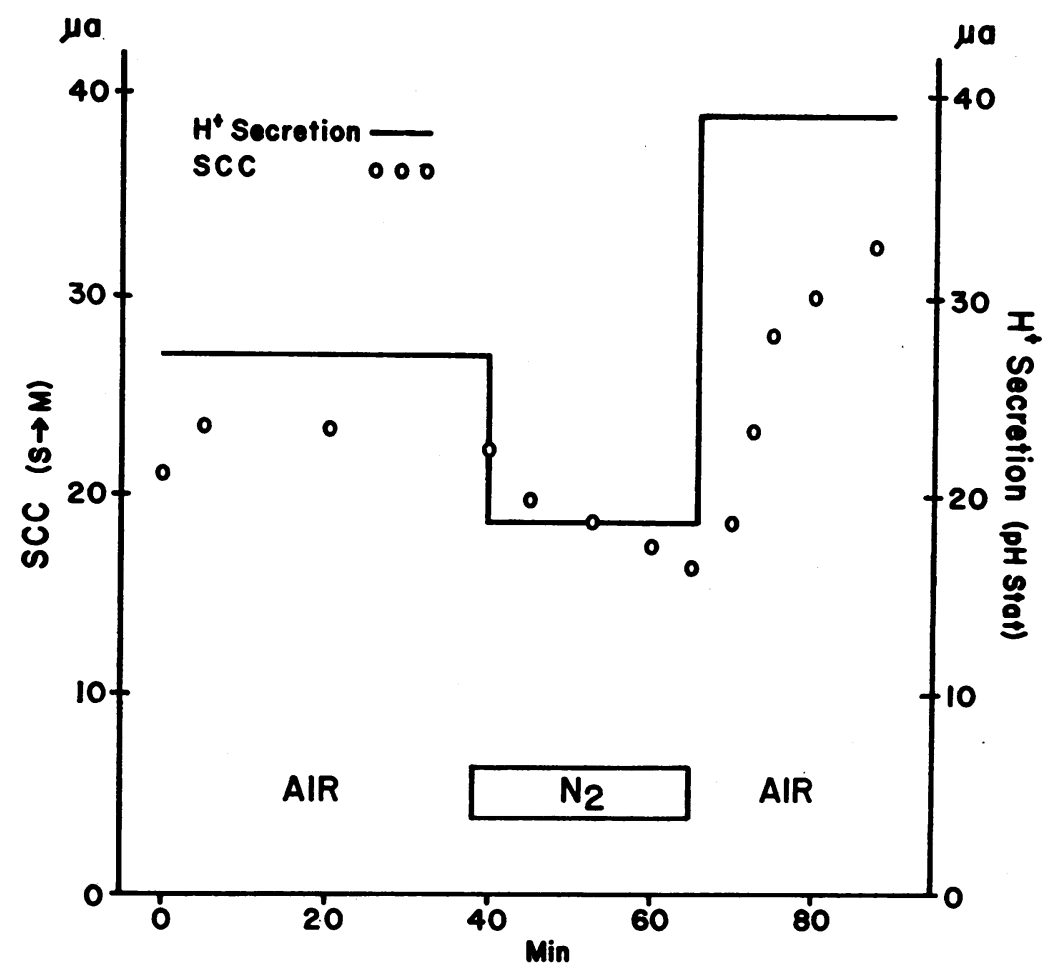

Fig. 1. Simultaneous measurement of the rate of $\mathrm{H}^{+}$Secretion by THE PH STAT METHOD AND THE SHORT-CIRCUIT CURRENT $(S C C)$. CsCl Ringer's solution was present on both surfaces of the bladder. The bathing solutions were deoxygenated with nitrogen during the interval indicated. The shortcircuit current has the polarity of positive charge transfer across the bladder from serosa $(S)$ to mucosa $(M)$.

of both the rate of $\mathrm{H}^{+}$secretion and the SCC. In four experiments the bathing media were again equilibrated with air; both the SCC and the rate of $\mathrm{H}^{+}$secretion increased significantly. The course of one such experiment is demonstrated in Fig. 1. In all six experiments restoration of $\mathrm{Na}^{+}$concentration to 115 mmoles/liter at the end of the period in Na-free Ringer's solution resulted in a prompt return of the positive PD across the bladder.

Effect of removal of $\mathrm{Cl}^{-}, \mathrm{K}^{+}$, or $\mathrm{Ca}^{++}$from the bathing solutions. The data in Table I, which gives an account of the $\mathrm{SCC}$ in $\mathrm{NaCl}$ and $\mathrm{Na}_{2} \mathrm{SO}_{4}$ Ringer's solutions indicate a significant difference between the rate of $\mathrm{H}^{+}$secretion in the two series of bladders. Although $\mathrm{H}^{+}$secretion was not abolished in any of the experiments in Cl-free Ringer's solution, the mean rate was about half to two-thirds the rate in standard $\mathrm{NaCl}$ Ringer's solution. The results of alternative experiments, in which each individual preparation was exposed sequentially to both $\mathrm{Cl}^{-}$and $\mathrm{SO}_{4}=$, are summarized in Table V. The initial rate of $\mathrm{H}^{+}$secretion after a wash period of about $30 \mathrm{~min}$ in $\mathrm{Na}_{2} \mathrm{SO}_{4}$ Ringer's solution was close to the control rate. During the 2 nd hr, however, the rate tended to decrease and become constant at a lower level.

TABLE V

Effect of $\mathrm{H}^{+}$secretion of substitution of $\mathrm{SO}_{4}^{-} \mathrm{fcr} \mathrm{Cl}^{-}$in solutions bathing turtle bladder

\begin{tabular}{ccccc}
\hline & \multicolumn{4}{c}{$\mathrm{H}^{+}$secretion* } \\
\cline { 2 - 5 } Turtle & $\begin{array}{c}\text { Initial } \\
\text { control }\end{array}$ & $\begin{array}{c}\text { SOt- } \\
\text { 1st hr }\end{array}$ & $\begin{array}{c}\text { SOt- } \\
\text { 2nd hr }\end{array}$ & $\begin{array}{l}\text { Final } \\
\text { control }\end{array}$ \\
\hline & \multicolumn{4}{c}{$\mu$ moles $/ h r$} \\
1 & 1.40 & 1.51 & 0.74 & 1.70 \\
2 & 0.70 & 0.57 & 0.27 & 0.65 \\
3 & 1.00 & 0.85 & 0.40 & 1.30 \\
4 & 0.65 & 0.65 & 0.40 & 0.55 \\
5 & 1.52 & 1.20 & 1.20 & 1.55 \\
6 & 0.68 & 1.00 & 0.55 & 0.75
\end{tabular}

* The experimental periods were of 30-40 min duration. The $\mathrm{SO}_{4}-$ periods were at the end of the $1 \mathrm{st}$ and $2 \mathrm{nd} \mathrm{hr}$ of exposure to $\mathrm{Na}_{2} \mathrm{SO}_{4}$ Ringer's solution. 

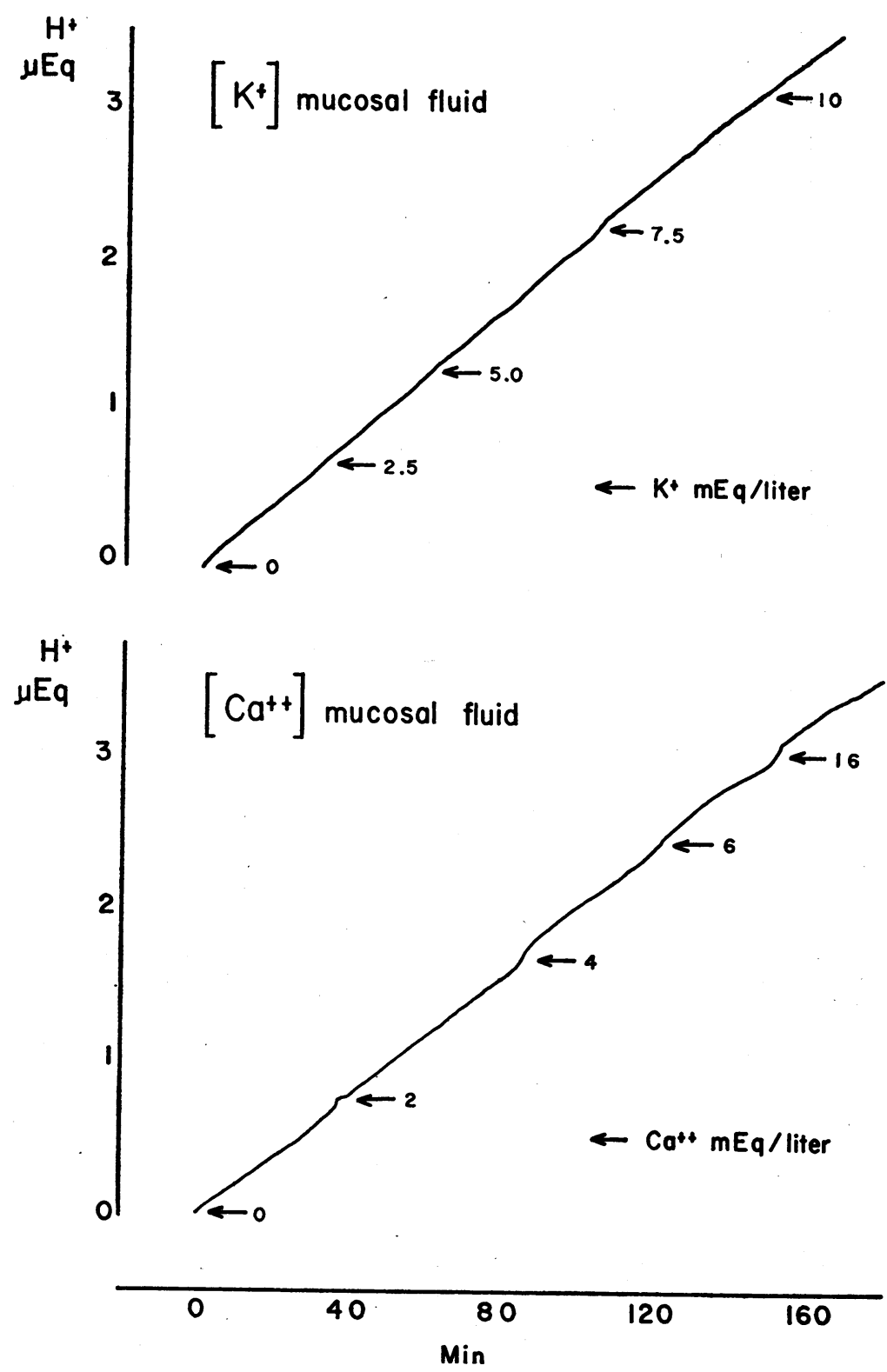

Fig. 2. EFfect on cumulative $\mathrm{H}^{+}$SeCRetion of variation of $\mathrm{K}^{+}$or $\mathrm{CA}^{++}$CONCENTRATION IN THE MUCOSAL FLUid. The mucosal surface of the bladder was washed three times with a Ringer's solution free from the test cation. After measurement of the control rate of $\mathrm{H}^{+}$secretion, small volumes of a solution of the test cation were added to the mucosal medium at intervals to yield the final concentrations shown in the figure.

Replacement of $\mathrm{Cl}^{-}$in the media was followed by a return of the rate of $\mathrm{H}^{+}$secretion to initial levels.

The influence of $\mathrm{Ca}^{++}$and $\mathrm{K}^{+}$in the mucosal medium on the rate of $\mathrm{H}^{+}$secretion was examined in a series of five experiments. The mucosal surface was washed three times with a solution which was free from $\mathrm{Ca}^{++}$or $\mathrm{K}^{+}$, but which was otherwise identical with the normal Ringer's solution which bathed the serosal surface. The bladder was than short-circuited and a control rate of $\mathrm{H}^{+}$ secretion was determined with either $\mathrm{K}^{+}$or $\mathrm{Ca}^{++}$ absent from the mucosal medium. At intervals of 
20-40 min small amounts of $\mathrm{KCl}-$ or $\mathrm{CaCl}_{2}$-containing solution were added to the mucosal medium to bring about a stepwise increase in the concentration of one of these ions.

Fig. 2 illustrates the results of two such experiments. Alteration of $\mathrm{K}^{+}$concentration in the range of $0-10 \mathrm{mEq} /$ liter failed to change the rate of $\mathrm{H}^{+}$secretion significantly. Although these experimental results cannot eliminate the possibility of tightly coupled $\mathrm{Ca}^{++}$or $\mathrm{K}^{+}$exchange as the basis of $\mathrm{H}^{+}$secretion, they make such a mechanism extremely unlikely.

\section{Discussion}

Passive driving forces fail to account for $\mathrm{H}^{+}$ transport in the isolated urinary bladder of the turtle (2). The alternative explanations for the process invoke coupling either to one of the energy-yielding reactions of intermediary metabolism or to the flow of another actively transported ion. The present study was designed to test the latter possibility.

The active transport of $\mathrm{Na}^{+}$from mucosal to serosal medium was eliminated by removal of $\mathrm{Na}^{+}$ from the ambient solution or inhibited by exposure of the bladder to dinitrophenol. Since neither maneuver altered the rate of $\mathrm{H}^{+}$secretion significantly, we have concluded that the energy for $\mathrm{H}^{+}$transport does not derive from the countertransport of $\mathrm{Na}^{+}$across the bladder.

The absence of coupling between $\mathrm{Na}^{+}$reabsorption and $\mathrm{H}^{+}$secretion in the isolated urinary bladder of the turtle is of interest because of the many physiologic and clinical observations in the intact kidney which indicate that part of $\mathrm{Na}^{+}$reabsorption in the renal tubule is linked to $\mathrm{H}^{+}$secretion (11-15). Although the cellular mechanisms of urinary acidification may well be different in the turtle bladder and the mammalian renal tubule, there are important similarities in the orientation of $\mathrm{H}^{+}$and $\mathrm{Na}^{+}$transport and in the maximal transcellular gradient of $\mathrm{pH}$ that can be reached in the two epithelia.

The absence of direct coupling between the transport of $\mathrm{Na}^{+}$and $\mathrm{H}^{+}$does not preclude an indirect relation between flows of the two ions. Thus, it should be emphasized that our comparisons of the rate of $\mathrm{H}^{+}$secretion in the presence and absence of $\mathrm{Na}^{+}$were made in the short-circuited state. In our previous paper we showed that the spontaneous $\mathrm{PD}$ generated by the active transport of $\mathrm{Na}^{+}$is a driving force which makes a small but definite contribution to the rate of $\mathrm{H}^{+}$ secretion. In studies of the intact kidney such an effect might be considerably magnified, since only a small fraction of total $\mathrm{H}^{+}$secretion appears in the final urine and an even smaller fraction of the filtered $\mathrm{Na}^{+}$escapes reabsorption along the tubule.

The original reason for comparing net $\mathrm{Na}^{+}$flux and SCC was to determine whether the latter could be used as a convenient and instantaneous measure of the former. In 57 periods in which the bladder was short-circuited and bathed in identical solutions, the difference between the simultaneously determined, unidirectional $\mathrm{Na}^{+}$fluxes exceeded the SCC by less than $6 \%$, both in the presence and absence of ambient $\mathrm{Cl}^{-}$. This result is the justification for our use of the SCC as an indicator of changes in $\mathrm{Na}^{+}$transport.

Klahr and Bricker, who employed a Ringer's solution of similar composition, found that the net flux of $\mathrm{Na}^{+}$was $11 \%$ less than the SCC (3).

On the other hand, Gonzalez and his associates reported in an abstract that the net flux of $\mathrm{Na}^{+}$ was 1.5 times the SCC (9). The basis for these discrepancies is not apparent at this time. There is agreement, however, that $\mathrm{Na}^{+}$is actively transported by the bladder in vitro and that net transport of $\mathrm{Na}^{+}$makes up the bulk of the SCC.

Gonzalez and associates (5) have demonstrated active transport of $\mathrm{Cl}^{-}$from $\mathrm{M}$ to $\mathrm{S}$ in the isolated turtle bladder. In principle, this process might be coupled in some way to that of $\mathrm{H}^{+}$transport and provide the driving force for the latter. Our demonstration that $\mathrm{H}^{+}$ion secretion continued despite virtual absence of $\mathrm{Cl}^{-}$from the medium is strong evidence against a coupling mechanism that depends on simultaneous and equivalent transport of $\mathrm{Cl}^{-}$from $\mathrm{M}$ to $\mathrm{S}$ and $\mathrm{H}^{+}$ion from $\mathrm{S}$ to $\mathrm{M}$.

As a by-product of the investigation of the relation between $\mathrm{Na}^{+}$transport and $\mathrm{H}^{+}$ion secretion, acid secretion was compared with the SCC in the presence of $\mathrm{Cl}^{-}$and the absence of $\mathrm{Na}^{+}$. The agreement between $\mathrm{H}^{+}$secretion and $\mathrm{SCC}$ in Table IV indicates that acidification accounts for all of the asymmetrical charge transport across the bladder epithelium, and hence, constitutes evidence against the active transport of $\mathrm{Cl}^{-}$under these experimental conditions. The basis for the apparent discrepancy between this result and the 
findings of Gonzalez et al. (5) has not been investigated, but there are several differences in the design of the two sets of experiments.

The coupling reaction responsible for $\mathrm{H}^{+}$secretion might involve the active transport of a mobile ion which is cycled across only one face of the cell and is not itself transported across the epithelium. Potassium, for example, has the role of mobile ion in the original model of active $\mathrm{Na}^{+}$transport in frog skin (16). For the reasons outlined in our previous study, the mechanism of $\mathrm{H}^{+}$secretion is probably located at the mucosal surface of the cell. Besides $\mathrm{Na}^{+}$, the only extracellular cations available for exchange at this site are $\mathrm{K}^{+}$and $\mathrm{Ca}^{++}$. Wide variation in the concentration of either of these ions in the mucosal medium was without significant effect on the rate of $\mathrm{H}^{+}$secretion.

A variant of this model is the ion-pair pump, which in this instance would bring about movement of $\mathrm{H}^{+}$across the mucosal boundary of the epithelial cell as an undissociated acid. The failure to demonstrate an increase in the buffer capacity of the mucosal medium after prolonged periods of acid secretion constitutes good evidence against such a mechanism (2).

At the present time, $\mathrm{H}^{+}$secretion is most satisfactorily described as a process which is located at the mucosal boundary of the epithelial cell, is directly coupled to metabolic energy production, and which in the short-circuited preparation transports the proton across the mucosal membrane without ion-pair formation or cationic exchange.

\section{Acknowledgments}

We are grateful to Mrs. Edith Delbrouck and Miss Joyce Stichman for technical assistance.

\section{References}

1. Steinmetz, P. R., and H. S Frazier. 1966. Characteristics of hydrogen ion transport in urinary bladder of the turtle J. Clin. Invest. 45: 1077. (Abstr.)

2. Steinmetz, P. R. 1967. Characteristics of hydrogen ion transport in urinary bladder of water turtle. J. Clin. Invest. $46: 1531$.
3. Klahr, S., and N. S. Bricker. 1964. Na transport by isolated turtle bladder during anaerobiosis and exposure to KCN. Am. J. Physiol. 206: 1333.

4. Brodsky, W. A., and T. P. Schilb. 1966. Ionic mechanisms for sodium and chloride transport across turtle bladders. Am. J. Physiol. 210: 987.

5. Gonzalez, C. F., Y. E. Shamoo, and W. A. Brodsky. 1967. Electrical nature of active chloride transport across short-circuited turtle bladders. Am. J. Physiol. 212 : 641.

6. Paine, C. M., and E. C. Foulkes. 1963. Sodium compartmentation in turtle bladder. Biochim. Biophys. Acta. 78 : 767.

7. Ussing, H. H. 1949. The distinction by means of tracers between active transport and diffusion. Acta Physiol. Scand. 19 : 43.

8. Civan, M. M., O. Kedem, and A. Leaf. 1966. Effect of vasopressin on toad bladder under conditions of zero net sodium transport. Am. J. Physiol. 211 : 569.

9. Gonzalez, C. F., Y. E. Shamoo, H. R. Wyssbrod, and W. A. Brodsky. 1966. Carriage of short-circuit current by transport of $\mathrm{Na}^{+}, \mathrm{Cl}^{-}$, and $\mathrm{HCO}_{3}{ }^{-}$across the reptilian bladder. Federation Proc. 25: 507. (Abstr.)

10. Bricker, N. S., and S. Klahr. 1966. Effects of dinitrophenol and oligomycin on the coupling between anaerobic metabolism and anaerobic sodium transport by the isolated turtle bladder. J. Gen. Physiol. 49: 483.

11. Pitts, R. F. 1948. Renal excretion of acid. Federation Proc. $7: 418$.

12. Schwartz, W. B., R. L. Jenson, and A. S. Relman. 1955. Acidification of the urine and increased ammonium excretion without change in acid-base equilibrium: sodium reabsorption as a stimulus to the acidifying process. J. Clin. Invest. $34: 673$.

13. Steinmetz, P. R., and N. Bank. 1963. Effects of acute increases in the excretion of solute and water on renal acid excretion in man. J. Clin. Invest. 42 : 1142.

14. Steinmetz, P. R., R. P. Eisinger, and J. Lowenstein. 1965. The excretion of acid in unilateral renal disease in man. J. Clin. Invest. $44: 582$.

15. Steinmetz, P. R., and R. P. Eisinger. 1966. Influence of posture and diurnal rhythm on the renal excretion of acid: Observations in normal and adrenalectomized subjects. Metabolism. 15: 76.

16. Koefoed-Johnsen, V., and H. H. Ussing. 1958. The nature of the frog skin potential. Acta Physiol. Scand. $42: 298$. 